\title{
Propagation of CAR Bacillus in Artificial Media
}

\author{
Yoko SHOJI*, Toshio ITOH, and Naoko KAGIYAMA \\ Central Institute for Experimental Animals, 1430 Nogawa, \\ Miyamae-ku, Kawasaki-shi, Kanagawa 216, Japan
}

(Received 4 September 1991/Accepted 19 November 1991)

\begin{abstract}
CAR bacillus propagated successfully in an artificial medium, and the number of CAR bacillus was about 30 times the original number after 8 days of cultivation. The medium consisted of Eagle's minimum essential medium supplemented with $10 \%$ fetal calf serum and $20 \%$ hamster tracheal organ culture soup. By intranasal inoculation to mice, two strains of the CAR bacillus passaged 5 and 6 times in this artificial medium produced the same lung lesions as natural CAR bacillus infection. - KEY WORDS : CAR bacillus, culture, medium
\end{abstract}

Cilia-associated respiratory (CAR) bacillus is a newly recognized respiratory pathogen in laboratory animals including mice and rats [1 $\sim 5]$. This organism can grow in the allantoic cavity of embryonated hen's eggs [1] and also by overlay cultivation on the $3 \mathrm{~T} 3$ cells, mouse fibroblast cell line [Waggie, K. S. Personal communication], but not in cell-free artificial media $[1,2]$. This brief communication describes the propagation of CAR bacillus in cellfree artificial media and the pathogenicity of the propagated bacilli to mice.

To examine the growth of CAR bacillus in culture media, the CBM strain [5] of CAR bacillus of mouse origin passaged in the allantoic cavity of 7-day-old chick embryos was used. The examination media were prepared with Eagle's minimum essential medium without antibiotics (MEM, Flow lab., USA) or Dulbecco's phosphate bufferred saline (PBS, Nissui, Tokyo) as basal media, and with fetal calf serum (FCS, GIBCO, USA) and hamster tracheal organ culture soup (HTS) as supplements. The HTS was prepared as follows. The tracheas of 4-week-old Syrian hamsters were taken aseptically, cut about 5 pieces in each and cultured with MEM supplemented with $10 \%$ FCS in
$5 \% \mathrm{CO}_{2}$ atmosphere for one month in a culture plate with 48 wells (Corster, USA). The culture medium was changed twice a week. Then, the culture soup was pooled and stored at $-20^{\circ} \mathrm{C}$. After filtration using a millipore filter (pore size $: 0.2 \mu \mathrm{m}$ ), the soup was used as HTS. To examine the growth of the CAR bacillus, $0.1 \mathrm{ml}$ of the CBM-infected allantoic fluid containing $2.0 \times 10^{7} \mathrm{bacilli} / \mathrm{ml}$ was inoculated in triplicate in a culture plate with 48 wells filled with 0.5 $\mathrm{ml}$ of each examination medium. Then, the inoculated culture plate was incubated at $37^{\circ} \mathrm{C}$ in $5 \% \mathrm{CO}_{2}$ atmosphere. After 7 days, the number of CAR bacillus in $5 \mu$ l of the culture medium spread over a $1 \mathrm{~cm}^{2}$ square area was estimated by a microscopic count of preparations stained with immunofluorescent staining.

As shown in Table 1, the CBM strain was successfully propagated in the both of MEM and PBS supplemented with 10\% FCS and 20\% HTS. However, the growth ratios in the respective media were 11 and 19 times, and lower than that of the chick embryos. Although there was no clear difference in the CBM strain counts between MEM and PBS, the CBM strain propagated with MEM as basal medium showed higher motility and firmer stainability than

*Present address : Meiji Seika Co, LTD. Morooka-cho, Kohoku-ku, Yokohama-shi, Kanagawa 222, Japan 
Table 1. Propagation of the CBM strain of CAR bacillus in artificial media

\begin{tabular}{lcc}
\hline \multicolumn{1}{c}{ Media } & $\begin{array}{c}\text { Mean bacterial count } \\
\text { after cultivation }(/ \mathrm{ml})\end{array}$ & Growth rate $^{*}$ \\
\hline MEM without supplements & $8.0 \times 10^{6}$ & 2.5 \\
MEM + FCS $(10 \%)$ & $5.0 \times 10^{6}$ & 1.6 \\
+ HTS $(20 \%)$ & $5.6 \times 10^{6}$ & 1.8 \\
+ FCS $(10 \%)+$ HTS $(20 \%)$ & $60.0 \times 10^{6}$ & 18.8 \\
PBS without supplements & $9.5 \times 10^{6}$ & 3.0 \\
PBS + FCS $(10 \%)$ & $9.9 \times 10^{6}$ & 3.1 \\
+ HTS $(20 \%)$ & $25.0 \times 10^{6}$ & 7.8 \\
+ FCS $(10 \%)+$ HTS $(20 \%)$ & $36.0 \times 10^{6}$ & 11.3 \\
(Original bacterial count : & $\left.3.2 \times 10^{6}\right)$ & \\
& & \\
Chick embryo & $95.0 \times 10^{6}$ & 79.2 \\
(Original bacterial count : & $\left.1.2 \times 10^{6}\right)$ & \\
\hline
\end{tabular}

* : Mean bacterial count / Original bacterial count

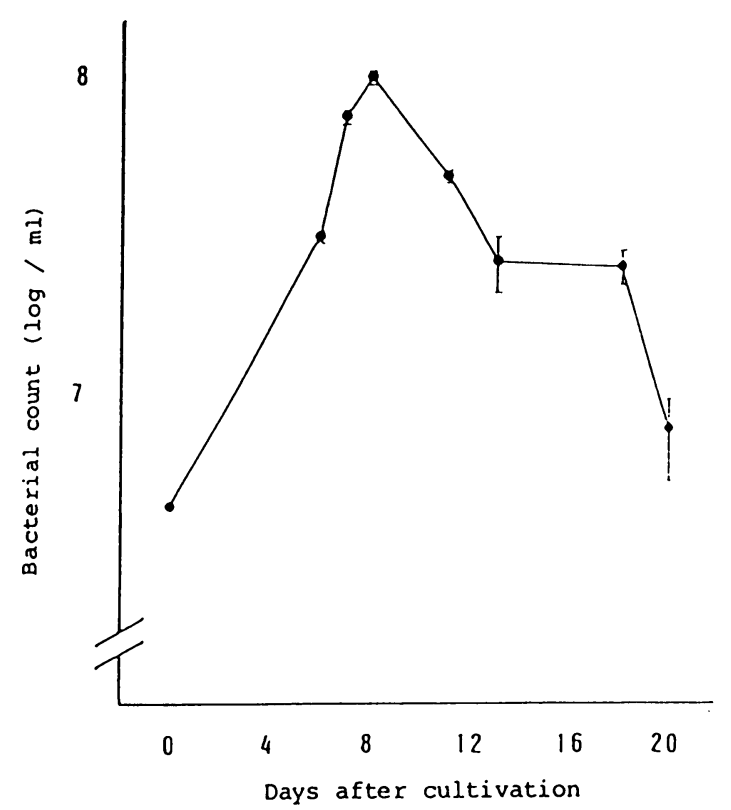

Fig. 1. Growth curve of the CBM strain of CAR bacillus in the medium

that propagated with PBS, suggesting their higher viability.

The growth curve of the CBM strain propagated in the present artificial medium (MEM suppremented with 10\% FCS and 20\% HTS) is shown in Fig. 1. After 8 days of culturing, the number of the CAR bacillus reached about 30 times the original number. The numbers decreased gradually during the 10 days following cultivation, and declined to the starting number at the end of the observation for 20 days. By microscopic observation as shown Fig. 2, the CAR bacillus propagated in this medium tended to aggregate easily in the medium, and propagated on the bottom of the well, which seemed like extention from the aggregates.

In order to elucidate the pathogenicity of the CAR bacillus propagated in this artificial medium, experimental infection to mice was examined. Two strains of CAR bacillus, mouse origin CBM and rat origin CBR strains [2], passaged in this medium 6 and 5 times in the same manner contained $0.9 \times 10^{7}$ and $1.6 \times 10^{7}$ bacilli $/ \mathrm{ml}$, respectively. Ten microliters of the passaged medium or the bacteria-free medium was inoculated intranasally under ether anesthesia into 4-week-old female Jcl : ICR mice (CLEA Japan, Tokyo) which had been confirmed free from Sendai virus, mouse hepatitis virus, mouse adenovirus, mouse poxvirus, Mycoplasma pulmonis, Pasteuella pneumotropica, Tyzzer's organism, Corynebacterium kutscheri and Salmonella typhimurium. Mice were housed in autoclaved cages with wood shavings as bedding and given $\gamma$ ray-irradiated pellets (CE-2, CLEA Japan, Tokyo) and tap water ad libitum. The animal room was controlled at 20 to $24^{\circ} \mathrm{C}$ and a $12 \mathrm{hr}$ light/dark cycle. After 8 weeks, these inoculated mice were sacrificed and subjected to pathological, bacteriolo- 

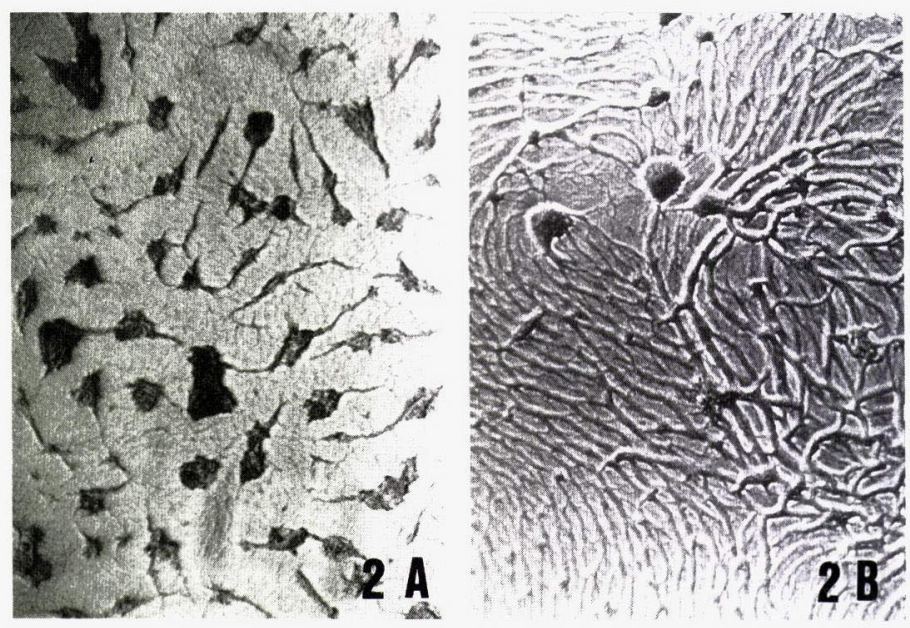

Fig. 2. Phase contrast photomicrograph of CAR bacillus in the medium $\times 100$ A : 6 days after cultivation B: 9 days after cultivation

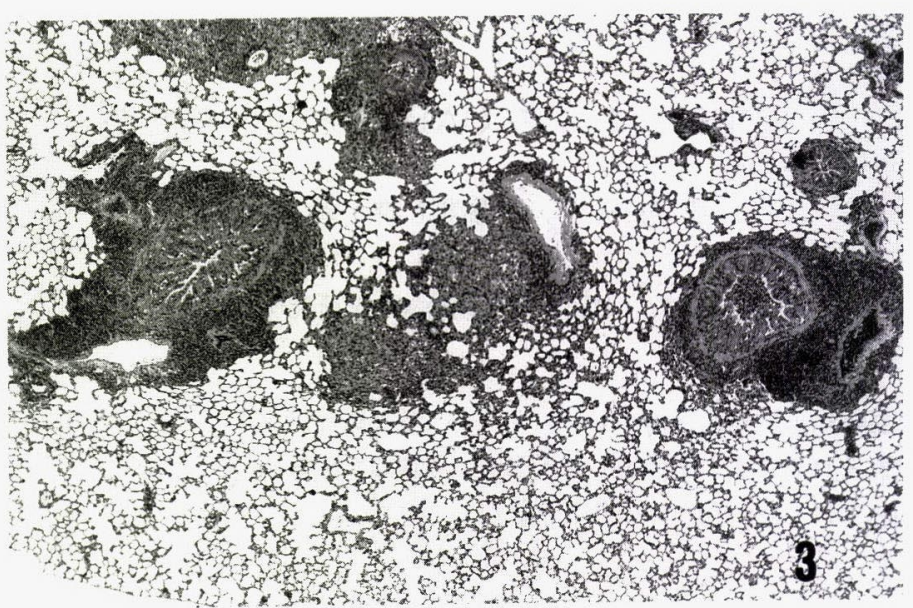

Fig. 3. Lung lesion of a mouse inoculated with CBM (6 th passage) $\mathrm{H}-\mathrm{E}$ stain $\times 10$

Table 2. Pathogenicity of CAR bacillus strains passaged in the medium to mice

\begin{tabular}{ccccc}
\hline $\begin{array}{c}\text { Inoculum } \\
\text { strains }\end{array}$ & Lung lesion & $\begin{array}{c}\text { Antigen* } \\
\text { in lungs }\end{array}$ & $\begin{array}{c}\text { Serum** } \\
\text { antibody }\end{array}$ & $\begin{array}{c}\text { CAR bacillus*** } \\
\text { isolation }\end{array}$ \\
\hline CBM (6th passage) & $5 / 5^{* * * *}$ & $5 / 5$ & $5 / 5$ & $5 / 5$ \\
CBR (5th passage) & $5 / 5$ & $5 / 5$ & $5 / 5$ & $5 / 5$ \\
Medium & $0 / 4$ & $0 / 4$ & $0 / 4$ & $0 / 4$ \\
\hline
\end{tabular}

* : Immunofluorescent method

* : ELISA method

*** : Inoculation

to chick embryo with the lung washout ${ }_{* * * *}$ : No. positive/ No. examined 
gical and serological examinations. The lung tissues were fixed in formalin, embedded in Paraplast + (Monoject, USA), and stained with hematoxylin and eosin for histopathological examination. Isolation of CAR bacillus from the lung washout was performed by the method using chick embryos described previously $[2,5]$. Detection of serum antibody against CAR bacillus was performed by ELISA as described previously [6]. These results are summarized in Table 2. Histopathologically, severe peribronchial lymphoid cell accumulation was observed in all of the inoculated mice (Fig. 3), and CAR bacillus was detected in the cilia of the bronchial epithelium by the indirect immunofluorescent staining described previously[2]. These lung lesions and the distribution of the pathogen were identical to natural and experimental CAR bacillus infection in mice and rats
[1 5]. Moreover, CAR bacillus was reisolated from the lung washouts of all mice. All of the inoculated mice were seroconverted. These findings indicate that CAR bacillus propagate successfully in artificial medium and the CAR bacillus passaged in this medium are pathogenic for mice.

\section{References}

[1] Ganaway, J. R, Spencer, T. H., Moore, T. D., and Allen, A. M. (1985). Infect. Immun, 47, 472-479.

[2] Itoh, T., Kohyama, K., Takakura, A., Takenouchi, T., and Kagiyama, N. (1987). Exp. Anim, 36, 387-393.

[3] Matsushita, S. (1986). Jpn J. Vet. Sci, 48, 437-440.

[4] Matsushita, S, Joshita, H., and Fukutsu, K. (1989). Lab. Anim, 23, 96-102.

[5] Shoji, Y., Itoh, T., and Kagiyama, N. (1988). Exp. Anum, 37, 447-453.

[6] Shoji, Y., Itoh, T., and Kagiyama, N. (1988). Exp. Anim, 37, 67-72.

\section{人工培地による CAR バチルスの培養}

庄司陽子・伊藤豊志雄・鍵 山直子

\section{財団法人実鈳動物中央研究所}

$\mathrm{CAR}$ バチルスが MEM 培地に牛胎仔血清とハムスタ 一気管の培㧼上清をそれぞれ10\%と20\%添加した人工培 地で増殖することを明らかにした。菌数は培養 8 日後に
接種時の30倍になった。さらに, 本培地で 5 から 6 代継 代した CAR バチルスのマウスに対する病原性す確認さ れた。 